\title{
Barangaroo Reserve Methods
}

\section{Research Fellows:}

Andrew Toland

Lecturer, School of Architecture

University of Technology Sydney

Simon Kilbane,

Senior Lecturer, School of Architecture

University of Technology Sydney

\section{Research Assistant:}

Kane Pham

Research Assistant, School of Design

University of Technology Sydney

\section{Firm Liaisons:}

Marta Gual

Associate

PWP Landscape Architecture

Adam Greenspan

Partner

PWP Landscape Architecture

This investigation was conducted as part of the Landscape Architecture Foundation's 2017 Case Study Investigation (CSI) program. CSI matches faculty-student research teams with design practitioners to document the benefits of exemplary high-performing landscape projects. Teams develop methods to quantify environmental, social, and economic benefits and produce Case Study Briefs for LAF's Landscape Performance Series.

The full case study can be found at:

https://landscapeperformance.org/case-study-briefs/barangaroo

To cite:

Toland, Andrew, Simon Kilbane, and Kane Pham. "Barangaroo Reserve Methods." Landscape Performance Series. Landscape Architecture Foundation, 2017. https://doi.org/10.31353/cs1241 


\section{ENVIRONMENTAL BENEFITS}

- Reconstructed the historic soil profile, resulting a 99\% success rate among approximately 76,000 newly-installed plants.

\section{Method}

The 99\% success rate for plant establishment comes from a statement by Stuart Pittendrigh, Sydney landscape architect, registered horticulturalist and aborist, who was retained as a consultant on the project, in a February 2016 article in Landscape Architecture Australia (McKenzie 2016).

The figure of approximately 76,000 for the number of plants installed comes from information provided by the Barangaroo Delivery Authority, the commissioning body and management authority for the park.

The typical rate for plant loss for a project at a comparable scale is $10-15 \%$, as compared to Barangaroo's 1\% plant loss (Pittendrigh, cited in BDA n.d.).

The plantings comprise 84 species of plants: 14 native trees, palms and tree ferns; 25 species of native groundcover, vines, grasses and ferns; and 45 species of native shrubs, small trees and Macrozamias. The planting palette was developed by Pittendrigh based on his historical research on Sydney's 1788 foreshore ecology (the date of the arrival of British colonists). 5 species are not native to Sydney Harbour headlands and were included for symbolic reasons because of the cultural significance as 'iconic' plants of the Sydney basin (Spotted Gum/Corymbia maculata, Gymea Lily/Doryanthes excelsa, Sydney Blue Gum/Eucalyptus saligna, Water Gum/Tristaniopsis laurina and Crimson Bottlebrush/Melaleuca citrina).

The role of the reconstructed soil profile in preventing plant loss, including discussion of the conceptual approach and testing used to produce reconstructed Hawkesbury sandstone bushland soils used to support the restored Sydney basin flora on the Barangaroo site is discussed in detail in Leake (2015) and Leake and Bryce (2017).

The reconstructed soil profile was made up from around 80\% recycled materials (Leake 2016), composed principally from crushed sandstone and sand from the excavations for the commercial developments on the Barangaroo South site, as well as recycled green garden waste compost and composted wood mulch from local government collections.

The principal challenge in the conceptual design of the reconstructed soil profile concerned the amount of compost and fertilizer to be included in the A horizon (topsoil) layer. Field research was conducted in areas of intact sandstone flora to gain a better understanding of the natural 'Kandosol' (yellow earth) soil characteristics of Sydney basin sandstone landscapes, taking samples of the profile and measuring nutrients and soil chemistry. The findings revealed strongly acidic soils ( $\mathrm{pH} 4.5-5.5)$ and some of the lowest levels of phosphorus in the world (25 $\mathrm{mg} / \mathrm{kg}$ in the sandstone layers, and 60-80 mg/kg in the topsoil layer) (Leake 2015; Leake 2016). 
Pot trials were then conducted to test a range of sandstone flora to optimise the levels of greenwaste compost to be used in various planting zones on the Barangaroo site: $5 \%$ by volume for sensitive sandstone heath areas; $10 \%$ for eucalyptus and woodland areas; and $20 \%$ for turf and fig tree open recreation areas (the latter not being part of the areas of reconstructed sandstone flora, but provided to meet the programmatic needs of the park) (Leake 2015; Leake 2016).

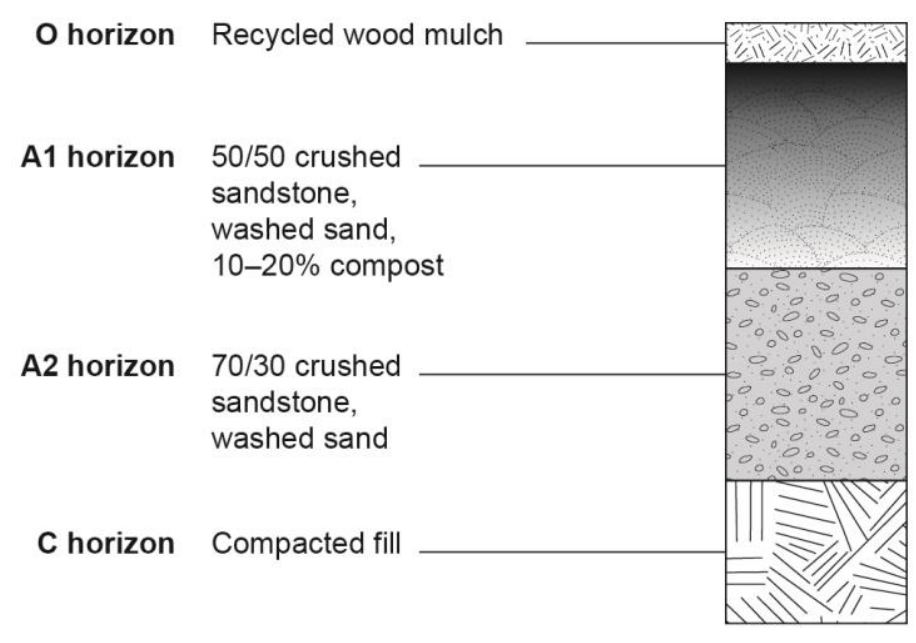

FIGURE 1: The Barangaroo 'Anthroposol': reconstructed Hawkesbury sandstone soil profile (based on Leake 2016).

\section{Limitations}

The results of the soil recreation process have led to better than normal plant survival rates. Although these figures are exemplary given the typical rate of attrition, it should be noted that reading the survival rates of plants is only partially reliant on the advances in the Anthroposol. A longitudinal study with replication in other environmental conditions would be required to evaluate the benefits against other variables such as rainfall, wildlife adaptation and introduction, and resilience to disease.

\section{Sources}

Barangaroo Delivery Authority. N.d. "Plants at Barangaroo Reserve." Accessed September 8, 2017, from http://www.barangaroo.com/see-and-do/the-stories/barangaroo-reserve-plants/

Leake, S.W. 2015. "Observations on Manganese Deficiency and Toxicity in some Australian native plants." Communications in Soil Science and Plant Analysis, 46(sup1), pp.176-187.

Leake, S.W. and Bryce, A. 2017. "Using Laboratory Analysis to Inform Adaptive Management," In Adaptive Soil Management: From Theory to Practices, Springer, Singapore, pp. 103-130.

Leake, S.W. 2016. "A Hyperlocal Soil Recipe," Landscape Architecture Magazine, 106.11 (November), pp. 78-135. 


\section{SOCIAL}

- Attracted over 250,000 visitors during the first 3 months of operation, and over $\mathbf{8 0 0 , 0 0 0}$ in the first 10 months. Approximately $\mathbf{4 0 \%}$ of total visitors in the first 10 months of operation attended for programmed events.

Method: General visitation

Figures obtained from the 2015-16 Barangaroo Delivery Authority Annual Report (BDA 2016, p. 7).

The research team has not been able to ascertain the method used by the Barangaroo Delivery Authority to calculate these visitor numbers. However, as a site managed by a government statutory authority, we assume that they use similar technologies and methodology to measure visitor numbers as the other statutory agency that was charged with the management of central areas of the Sydney Harbour waterfront, the Sydney Harbour Foreshore Authority (now incorporated into Property NSW). The SHFA/Property NSW uses infrared people counters installed at key locations in its central harbourfront properties. Calibration and expansion calculations are applied to raw counts in order to produce final figures that estimate total pedestrian flow (SHFA 2015, p. 5).

Total visitation for the first three months is an estimated 250,000 . Total visitation for the first 10 months of operation is 800,000 . The average monthly visitation figures for the first three months (called the "Welcome Celebration") of approximately 83,333 per month compares to a monthly average for the subsequent 7 months of around 78,571 per month, with 4,762 fewer visitors per month in the 7 months after the 3-month Welcome Celebration.

$$
\begin{aligned}
& 250,000 / 3=83,333 \\
& (800,000-250,000) /(10-3)=78,571 \\
& 83,333-78,571=4,762
\end{aligned}
$$

Method: Event visitation

Data was obtained from the 2015-16 Barangaroo Delivery Authority Annual Report (BDA 2016, p. 18) and from direct correspondence with the BDA (the figure for total event visitor numbers between the opening of the Reserve and the end of June 2016).

Barangaroo Reserve officially opened to the public on August 22, 2015. The opening was followed by a 3-month "Welcome Celebration" activation program, described in the BDA Annual Report (p. 18), as follows:

The Welcome Celebration featured engaging, family-friendly, accessible and educational events including:

- Specially-commissioned large-scale art installations by Aboriginal artist Brook Andrew, ESEM Projects, and James Dive and The Glue Society 
- 132 performances from 225 emerging and established performers, 45 bands and curated pyrotechnics

- Aboriginal ceremonies including a Welcome to Country and Dusk Ceremony

- 30 talks by community representatives including Shane Phillips from the Banjalung, Wonnarua and Eora peoples, and facilitator Aden Ridgeway

- 8 workshops and Aboriginal cultural tours for 927 participants

- A bespoke food and beverage menu by 23 local chefs, including Christine Manfield, Adriano Zumbo and Aboriginal chef Clayton Donovan.

The number of visitors brought in by programmed events $(316,224)$ between August 2015 and June 2016 compared to the total visitor numbers (approx. 800,000), reveals the importance of programmed events in attracting visitors to the site - in other words, around $40 \%$ of visitors to the site over that time period attended for specific programmed events.

$$
316,224 / 800,000=39.528 \%
$$

\section{Limitations}

The opening three months were inherently important for activation and were heavily programmed with inauguration events, so the figures may result in a slightly artificial total because of this. Nevertheless ongoing programming of large events at Barangaroo Reserve and its positioning as an iconic space may mean that it continues to attract large visitor numbers. On the other hand, as the park is still maturing especially in the plantings, a more mature park could also attract a greater baseline public in the attendance counts.

The research team was not able to ascertain details on the methodology used by the BDA to record visitor numbers, or details for their survey collection for the 2015 New Year's event. Because the New Year's event was ticketed, we assume that the number of attendees recorded for that event comes from the number of tickets sold. We have been unable to ascertain how visitor numbers for other events were recorded.

\section{Sources}

Barangaroo Delivery Authority (BDA), 2016. 2015-16 Barangaroo Delivery Authority Annual Report. NSW Government, Sydney.

Sydney Harbour Foreshore Authority (SHFA), 2015. Sydney Harbour Foreshore Authority Annual Report 2014-2015. NSW Government, Sydney.

Personal communication with Barangaroo Delivery Authority, July 2017. 
- Provides a high level of visitor satisfaction with $95 \%$ of surveyed visitors reporting that they were satisfied and would recommend the Reserve to others or visit again.

This figure was reported in the 2015-16 Barangaroo Delivery Authority Annual Report (BDA, 2016, p. 26).

The Annual Report states (BDA 2016, p. 26):

\section{Visitor sentiment}

During the year, the Authority expanded its market research to include feedback from visitors to the Reserve. Two rounds of research have been conducted. Overall, visitors expressed a high level of satisfaction with their experience, with more than 95\% saying they were satisfied and would recommend the Reserve to others or visit again.

Most day-to-day visitors were from the local Sydney region, although during events the visitor profile extended to Greater Sydney, NSW and Australia-wide. Some 20\% of event attendees were from overseas. The most common feature people came to see or experience was 'the ability to walk down to the water of Sydney Harbour' with the landscaping including sandstone features, native vegetation and the Cutaway also mentioned as highlights.

\section{Limitations}

The research team was not able to ascertain from the Barangaroo Delivery Authority data on the sample sizes or methodology that lies behind this survey, or copies of the survey reports themselves. It would have been valuable to have coded data to give a more finely grained analysis of these general perceptions.

\section{Sources}

Barangaroo Delivery Authority (BDA), 2016. 2015-16 Barangaroo Delivery Authority Annual Report. NSW Government, Sydney.

- Stimulated interest in the Barangaroo district as evidenced by an increase in the number of followers on social media platforms from 6,318 in 2015 to 22,002 in 2016, a 250\% increase.

\section{Method}

The number of followers of and subscribers to the 5 official social media accounts maintained by the Barangaroo Delivery Authority in the period around the opening of Barangaroo Reserve on 22 August 2015. Data compiled by the Barangaroo Authority is as follows: 


\begin{tabular}{|l|l|l|l|}
\hline Platform & June 30, 2015 & June 30, 2016 & Increase year-to-year \\
\hline Facebook & 3,095 followers & 14,038 followers & $+354 \%$ \\
\hline Instagram & 507 followers & 3,942 followers & $+678 \%$ \\
\hline Twitter & $\begin{array}{l}2,657 \text { (approx.) } \\
\text { followers }\end{array}$ & 3,768 followers & $+42 \%$ \\
\hline Linkedln & 2,621 followers & 3,872 followers & $+48 \%$ \\
\hline YouTube & 95 subscribers & 150 subscribers & $+58 \%$ \\
\hline $\begin{array}{l}\text { Total } \\
\text { followers/subscribers }\end{array}$ & $\mathbf{6 , 3 1 8}$ & $\mathbf{2 2 , 0 0 2}$ & $\mathbf{+ 2 4 8 \%}$ \\
\hline
\end{tabular}

TABLE 1: Social media statistics for official Barangaroo social media accounts maintained by the Barangaroo Delivery Authority (based on BDA 2016, p. 28).

The increase in interest and profile of the project are also supported by data for the official Barangaroo websites. In the lead-up to and around the time of the opening of Barangaroo Reserve in 2016, the Barangaroo Delivery Authority maintained two websites for the project, Barangaroo.com and Barangaroo.sydney (the latter now redirects to barangaroo.com). The website traffic data recorded by the BDA for this period is as follows:

\begin{tabular}{|l|l|l|l|l|}
\hline & \multicolumn{3}{|c|}{ Barangraoo.com } & Barangaroo.sydney \\
\hline & $2014-15$ & $2015-16$ & $\begin{array}{l}\text { Increase year-on- } \\
\text { year }\end{array}$ & 2015-16 (part) \\
\hline Sessions & 198,265 & 401,890 & $203 \%$ & 230,763 \\
\hline Page views & 584,550 & $1,116,043$ & $190 \%$ & 545,372 \\
\hline
\end{tabular}

TABLE 2: Website data for official Barangaroo websites maintained by the Barangaroo Delivery Authority (based on BDA 2016, p. 28).

The BDA attributes this to the increased production of images, storytelling content, and videos made available over this time period (BDA 2016, p. 28), but presumably it also relates to general publicity around the opening of the project across a range of media, including traditional media.

\section{Limitations}

The social media accounts and websites relate to the development of the entire Barangaroo redevelopment site, not just the Barangaroo Reserve headland park. Because of the high profile 
nature of the overall development, it is impossible to determine how much of the social media activity and website traffic might have been related to interest or concern with the overall

Barangaroo development and how much was generated by interest in Barangaroo Reserve and its opening to the public in August 2015.

Further disaggregation would provide better insight into the visitorship of individual users across platforms, and tracking of search terms could provide for a more nuanced understanding of the changes over time.

\section{Sources}

Barangaroo Delivery Authority (BDA), 2016. 2015-16 Barangaroo Delivery Authority Annual Report. NSW Government, Sydney. 


\section{APPENDIX \\ Plantings}

\section{TREES}

\section{Species}

Allocasuarina littoralis

Angophora costata

Banksia integrifolia

Corymbia gummifera

Corymbia maculata

Eucalyptus haemastoma

Eucalyptus pilularis

Eucalyptus piperita

Eucalyptus punctata

Eucalyptus saligna

Eucalyptus tereticornis

Ficus macrophylla

Ficus rubiginosa

Livistona australis

Platanus orientalis digitata

\section{GROUNDCOVER}

\section{Species}

Billardiera scandens

Blechnum nudum

Blechnum patersonii

Carpobrotus claucescens

Cheilanthes austrotenuifolia

Cissus antarctica

\section{Common name}

Black She-oak

Sydney Red Gum

Coast Banksia

Red Bloodwood

Spotted Gum

Scribbly Gum

Blackbutt

Sydney Peppermint

Grey Gum

Sydney Blue Gum

Forest Red Gum

Moreton Bay Fig

Port Jackson Fig

Cabbage Tree Palm

Cut Leaf Plane Tree

\section{Common name}

Hairy Apple Berry

Fishbone Water Fern

Strap Water Fern

Pigface

Rock Fern

Kangaroo Vine 
Cissus hypoglauca

Clematis aristata

Clematis glycinoides

Danthonia richardsonii

Davallia solida var. pyxidata

Dianella caerulea

Dianella revoluta

Gleichenia microphylla

Hardenbergia violacea

Hibbertia scandens

Isolepis nodosa

Kennedia rubicunda

Lomandra longifolia

Pandorea pandorana

Sarcocornia quinqueflora

Tetragonia tetragoniodes

\section{SHRUBS}

\section{Species}

Acacia floribunda

Acacia longifolia

Acacia myrtifolia

Acacia terminalis

Acacia ulicifolia

Acmena smithii

Allocasuarina littoralis

Banksia marginata

Banksia robur
Native Grape

Old Man's Beard

Forest Clematis

Wallaby Grass

Hare's-foot Fern

Paroo Lily

Blueberry Lily

Scrambling Coral Pea

Purple Coral Pea

Climbing Guinea Flower

Golden Guinea Vine

Dusky Coral Pea

Mat Rush

Wonga Wonga Vine

Samphire

New Zealand Spinach

\section{Common name}

White Sally Wattle

Sallow Wattle

Red-stemmed Wattle

Sunshine Wattle

Prickly Moses

Lilly Pilly

Black She-oak

Silver Banksia

Swamp Banksia 


\begin{tabular}{|c|c|}
\hline Banksia serrata & Old-man Banksia \\
\hline Banksia spinulosa & Hairpin Banksia \\
\hline Bauera rubioides & River Rose \\
\hline Boronia ledifolia & Showy Boronia \\
\hline Callicoma serratifolia & Black Wattle \\
\hline Callistemon citrinus & Crimson Bottlebrush \\
\hline Callistemon linearis & Narrow-leaved Bottlebrush \\
\hline Ceratopetalum gummiferum & NSW Christmas Bush \\
\hline Correa alba & White Correa \\
\hline Correa reflexa & Common Correa \\
\hline Callitris rhomboidea & Port Jackson Pine \\
\hline Cyathea australis & Black Tree-fern \\
\hline Dillwynia retorta & Heathy Parrot Pea \\
\hline Dodonaea triquetra & Large-leaf Hop Bush \\
\hline Doryanthes excelsa & Giant Lily \\
\hline $\begin{array}{l}\text { Eriostemon australasius (Philtheca } \\
\text { myoporoidea) }\end{array}$ & Pink Wax Flower \\
\hline Glochidion ferdinandi & Cheese Tree \\
\hline Grevillea buxifolia & Grey Spider Flower \\
\hline Grevillea linearifolia & Linear-leaf Grevillea \\
\hline Grevillea sericea & Pink Spider Flower \\
\hline Hakea teretifolia & Needlebush \\
\hline Hakea dactyloides & Finger Hakea \\
\hline Hibiscus tiliaceus & Cottonwood Hibiscus \\
\hline Isopogon anemonifolius & Broad-leaf Drumsticks \\
\hline Lambertia formosa & Mountain Devil \\
\hline Leptospermum juniperinum & Prickly Tea Tree \\
\hline Macrozamia communis & Burrawang \\
\hline Melaleuca hypericifolia & Hillock Bush \\
\hline
\end{tabular}


Melaleuca nodosa

Notelaea longifolia

Olearia tomentosa

Omalanthus populifolius

Persoonia levis

Pittosporum undulatum

Telopea speciosissima

Tristaniopsis laurina

Westringia fruticosa
Prickly-leaved Paperbark

Large Mock-olive

Toothed Daisy Bush

Native Bleeding Heart

Broad-leaved Geebung

Native Daphne

Waratah

Luscious Water Gum

Coastal Rosemary 